\title{
MEREKA YANG TERCERABUT DARI MASA DEPANNYA: Analisis Sosiologis Problem Sosial Anak di Indonesia
}

\author{
Thohir Yuli Kusmanto
}

Fakultas Dakwah dan Komunikasi

IAIN Walisongo Semarang

\begin{abstract}
Abstrak
Anak merupakan aset yang berharga bagi sebuah keluarga dan masyarakat dalam merengkuh kehidupan kolektifnya untuk menyongsong masa depan. Keluarga dan masyarakat yang peduli pada anak dalam rangka tumbuh dan berkembang secara manusiawi, sedang berinvestasi yang akan sangat menguntungkan bagi keberlangsungan hidupnya. Untuk itu mereka rela mencurahkan tenaga, biaya dan pikirannya demi tumbuh dan berkembangnya anak secara lebih baik. Lingkungan dan dukungan sosial kemasyarakatan yang baik, akan menjadikan anak sebagai satu generasi yang baik. Indikasinya dapat dilihat pada kemampuannya untuk berperan sosial sesuai harapan dan keinginan masyarakatnya. Namun demikian tidak semua anak memiliki kesempatan untuk tumbuh dan berkembang secara lebih baik dalam kehidupannya. Banyak dari mereka yang menghadapi masalah sosial yang serius, baik psiokologis, fisiologis, ekonomis dan lain-lainnya. Berbagai persoalan yang ada tersebut, merupakan sesuatu yang tidak dikehendakinya. Kondisi eksternal di luar dirinyalah yang paling banyak menjadi penyebabnya. Baik dari lingkungan yang paling kecil yaitu keluarga, maupun lingkungan yang luas yaitu masyarakatnya, bahkan negara. Berdasar realitas tersebut penulis tertarik untuk menelaah secara sosiologis problem sosial anak di Indonesia, dalam makalah ini.
\end{abstract}

Kata Kunci: anak, masalah sosial, tumbuh kembang

\section{A. Pendahuluan}

Kehadiran seorang anak merupakan berkah yang luar biasa bagi sebuah keluarga yang setelah sekian lama menjalani kehidupan rumah tangga. Bagi seorang ibu melahirkan anak dengan selamat dan mampu me- 
meliharanya secara baik merupakan kesempurnaan sebagai manusia. Bagi bapak bisa memiliki anak sebagai keturunannya merupakan pertanda sebagai lelaki yang sejati. Berbagai kebahagiaan menyeliputi sebuah keluarga ketika mereka memiliki anak. Namun demikian tidak semua orang bisa merasakan kebahagiaan dengan hadirnya anak. Anak bisa menjadi beban kehidupannya, karena kehadirannya tidak harapkan. Kehadirannya akan menambah beban sebuah keluarga ketika secara ekonomi, mereka akan menambah tingkat konsumsi.

Pada keluarga yang berkecukupan dan kedua orang tua semuanya bekerja, anak bisa jadi sesuatu yang merepotkan. Orang tua harus berbagi perhatian antara karier kerja dan tumbuh kembang anak. Banyak dari keluarga yang seperti ini mengandalkan pihak lain untuk menangani anakanak mereka, dengan cara menggunakan jasa pembantu rumah tangga atau pengasuh anak. Akibatnya frekuensi dan kualitas hubungan emosional dengan anak menjadi terbatas atau rendah. Rendahnya frekuensi dan kualitas hubungan akan berdampak pada psikis anak. Anak akhirnya mencari perhatian di tempat lain, karena keluarga tidak cukup memberi ruang bagi tumbuh kembangnya.

Pada keluarga yang berlatar belakang ekonomi dalam kemiskinan, anak menjadi beban keluarga, karena untuk memenuhi kebutuhan ekonomi, pendidikan, kesehatan dan berbagai persoalan lain, pendapatan ekonomi orang tua tidak cukup. Baik pada tingkat pemenuhan kebutuhan minimum maupun tingkat yang layak bagi seorang anak dalam mendukung tumbuh dan kembangnya sebagai manusia. Padahal kewajiban dan tanggung jawab orang tua adalah mencukupi kebutuhan anak sesuai dengan kebutuhan tumbuh dan kembangnya untuk menjadi diri yang berharkat dan bermartabat. Berbagai fenomena tersebut menghadapkan anak pada kehidupan yang sarat dengan masalah. Sebuah persoalan sosial yang kompleks harus dihadapinya, padahal mereka tidak menghendaki atau pun mengerti mengapa harus bergelut dengan persoalan tersebut dalam hidupnya. Apalagi persoalan tersebut tumbuh sangat akut dalam lingkungan sosialnya. 
Fenomena persoalan sosial anak tersebut merupakan gejala global yang dihadapi oleh banyak negara di dunia ini, baik mereka yang merupakan negara maju maupun yang merupakan negara berkembang (miskin dan terbelakang). Indonesia merupakan bagian dari negara yang memiliki problem sosial anak yang sangat kompleks tersebut. Meskipun secara kelembagaan dan politik negara telah memiliki berbagai kebijakan untuk mengatasi problem tersebut. Kebijakan negara bisa dilihat dari upaya membentuk kelembagaan hingga penganggaran untuk mendukung program kelembagaan tersebut.

Problem sosial anak di Indonesia tersebar merata di berbagai wilayah. Dari wilayah yang jauh dari peradaban hingga pusatnya peradaban. Tidak pandang wilayah perdesaan atau perkotaan, semua ada dan cenderung meningkat. Berdasarkan data yang diterima Kompas.com dari Direktorat Jenderal Pelayanan dan Rehabilitasi Sosial Kementerian Sosial RI, jumlah anak penyandang masalah kesejahteraan sosial (usia 0-18 tahun) di Indonesia per Desember 2009 mencapai 4.656 .913 jiwa atau setara dengan jumlah penduduk negeri jiran, Singapura. Menurut data tersebut, mereka yang disebut penyandang masalah kesejahteraan sosial anak adalah anak balita terlantar, anak terlantar, anak jalanan, dan anak nakal atau anak yang berhadapan dengan hukum. ${ }^{1}$ Namun demikian masih ada anak yang bermasalah sosial lainnya yang tidak diungkap oleh kementerian sosial tersebut yaitu anak korban tindak kekerasan terhadap anak (child abuse).

Meningkatnya problem sosial anak tersebut, sesungguhnya merupakan lampu kuning bagi sebuah negara bangsa akan masa depannya. Bagaimanapun keberadaan anak tersebut merupakan satu generasi yang melanjutkan estafet penyelenggaraan suatu negara. Oleh karenanya jika satu generasi dalam satu negara bangsa bermasalah, maka akan menjadi problem serius pada keberlangsungan suatu negara pada waktu tertentu. Apalagi jika kondisi yang tidak dikendaki tersebut berlarut-larut, dalam perjalanan

${ }^{1}$ http://edukasi.kompas.com/read/2010/02/17/12463026/Jumlah.Anak.Bermasalah.In donesia.Setara.Jumlah.Penduduk.Singapura. Diunduh jam 7.33 pada tanggal 2 Februari 2011. 
kehidupan tumbuh dan berkembangnya anak, maka dampaknya akan sangat luas dan lama.

Keluarga dan masyarakat memiliki kontribusi yang sangat signifikan atas berkembangnya masalah sosial anak. Keduanya harus memahami kebutuhan akan tumbuh dan berkembangnya anak, kalau tidak maka anak akan mengalami masalah yang berat atas kehidupannya. Kehidupan anak bisa dipahami dalam tiga perspektif; perspektif diri, keluarga dan masyarakat.

\section{B. Makna Sosial Anak dalam Masyarakat}

Sebagai diri seorang anak memiliki posisi dan makna yang berbeda dengan remaja, dewasa dan orang tua. Anak memiliki dunianya yang khas dengan situasi dan kondisinya. Alam pikir, cara pandang, hasrat, harapan dan keinginan tentang makna kehidupan sangat ditentukan oleh pemaknaannya sendiri. Perilaku dalam kesehariannya merupakan ekspresi dari proses pemaknaan tersebut dan ditopang oleh bakat dan kondisi bawaan dari sejak lahir. Perspektif kediriannya itulah yang harus dihargai oleh lingkungan keluarga dan masyarakat dalam memahami anak sebagai dirinya. Keluarga dan masyarakat memiliki andil dalam proses pembentukan dan pencarian jati diri anak agar bisa berperan dalam kehidupan sosial di lingkungannya, sesuai harapan dan tujuan bersama.

Proses tersebut tentu memerlukan waktu, tidak bisa terjadi secara tibatiba. Pengalaman keluarga dan masyarakat yang telah sekian lama menjadi pihak yang mendampingi, membimbing dan membina anak dalam tumbuh dan kembangnya, merupakan sumber pengetahuan yang luar biasa berarti. Adanya sumber pengetahuan yang telah teruji dalam rentang waktu yang lama maka memudahkan peran keluarga dan masyarakat. Pembentukan kepribadian anak agar bisa berperan secara baik di lingkungan keluarga dan masyarakatnya, tidak bisa mengesampingkan dimensi sosiologis dan psikologis anak. Mereka membutuhkan ruang dan waktu yang khas anak, dalam proses pertumbuhan dan perkembangan. Secara sosiologis anak butuh kemampuan untuk belajar peran dan status yang dimilikinya. Anak butuh belajar untuk berinteraksi sosial dengan orang lain di sekitarnya. Dalam proses interaksi tersebut anak harus mampu memahami diri dan 
orang lain, sehingga bisa menghargai, menghormati, memberi dan membutuhkan, bertoleransi dan banyak aspek sosiologis yang lain. Proses ini menjadi cara dan jalan bagi anak dalam memahami situasi sosial masyarakatnya secara lebih luas, agar ia bisa diterima dan menerima orang lain dalam kehidupannya.

Untuk mencapai situasi tersebut seorang anak butuh situasi dan kondisi yang relevan dengan kebutuhannya. Anak membutuhkan bimbingan dan kasih sayang oleh orang dewasa di sekitarnya, agar bisa belajar sosial tentang kehidupan. Anak membutuhkan jaminan perlindungan dan kesehatan fisik dan mental, karena lingkungan kehidupannya tidak sepenuhnya ramah dan pro pada kondisinya. Lingkungan yang tidak ramah dan pro pada kondisi anak, seringkali akan berakibat pada buruknya kondisi kesehatan fisik dan mental anak. Tumbuh dan kembang anak menjadi tidak wajar. Bahkan lebih buruk lagi anak gagal menjadi dirinya sebagai manusia yang berharkat dan bermartabat, yang bernilai lebih bagi kehidupan.

Pertumbuhan dan perkembangan yang tidak wajar pada anak, menjadikannya mengalami gangguan dalam proses belajar tentang status dan peranannya bagi kehidupan. Anak tidak bisa berperilaku sesuai status dan peran yang diharapkan oleh lingkungannya. Perilaku anak yang menyimpang dari harapan lingkungannya seringkali dianggap atau dinilai sebagai masalah atau penyakit sosial. Masalah sosial anak dalam masyarakat, pada dasarnya bermuara pada problem sosial dan psikologis yang akut, saat mereka tumbuh dan berkembang. Sebagai akibat dari faktor bawaan yang memiliki sesuatu yang terbatas dan kondisi lingkungan sosial yang buruk.

Kesadaran diri masyarakat tentang nilai dalam konteks kenegaraan dan kebangsaan di Indonesia sangat jelas tertuang dalam UU RI No. 23 Tahun 2002 tentang Perlindungan Anak. Pada bagian umum penjelasan atas UU tersebut menyatakan bahwa dalam diri seorang anak melekat di dalamnya harkat, martabat, dan hak-hak sebagai manusia yang harus dijunjung tinggi. Hak asasi anak merupakan bagian dari hak-hak asasi manusia sebagaimana termuat dalam Undang-Undang Dasar 1945 dan Konvensi Perserikatan Bangsa-Bangsa tentang Hak-Hak Anak. Anak dalam kehidupannya memiliki nilai yang strategis, baik untuk dirinya sendiri, 
keluarga, masyarakat, bangsa dan negara. Dari sisi kehidupan berbangsa dan bernegara, anak merupakan masa depan bangsa dan generasi penerus cita-cita bangsa, sehingga setiap anak berhak atas kelangsungan hidup, tumbuh dan berkembang, berpartisipasi serta berhak atas perlindungan dari tindak kekerasan dan diskriminasi serta hak sipil dan kebebasan.

Tanggung jawab negara terhadap anak-anak yang mengalami masalah sosial secara yuridis sesungguhnya sangat jelas sebagaimana diatur dalam Undang-Undang Republik Indonesia Nomor 23 Tahun 2002 tentang Perlindungan Anak pasal 59. Dalam pasal tersebut dinyatakan bahwa pemerintah dan lembaga negara lainnya berkewajiban dan bertanggungjawab untuk memberikan perlindungan khusus kepada anak dalam situasi darurat, anak yang berhadapan dengan hukum, anak dari kelompok minoritas dan terisolasi, anak tereksploitasi secara ekonomi dan/atau seksual, anak yang diperdagangkan, anak yang menjadi korban penyalahgunaan narkotika, alkohol, psikotropika, dan zat adiktif lainnya (napza), anak korban penculikan, penjualan dan perdagangan, anak korban kekerasan baik fisik dan/atau mental, anak yang menyandang cacat, dan anak korban perlakuan salah dan penelantaran. ${ }^{2}$

Peningkatan masalah sosial anak tersebut menjadi salah satu barometer dari rusaknya tata kelola negara. Negara dengan segala aparatusnya telah gagal memberikan jaminan kesejahteraan bagi warganya. Produkproduk kebijakan negara kurang pro atau memberikan perhatian yang cukup luas dan dalam, terhadap masalah kesejahteraan sosial warganya. Kebijakan negara seringkali bersifat parsial terhadap masalah sosial anak. Negara akan memberikan perhatian khusus pada persoalan-persoalan yang menguntungkan secara ekonomi dan politis. Bahkan lebih buruk lagi hanya menguntungkan kelompok-kelompok politis tertentu, hanya karena mereka yang telah menjadikannya berkuasa.

Berkembangnya permasalahan sosial anak, merupakan mata rantai dari permasalahan sosial yang lain, yang kebanyakan merupakan masalah sosial

\footnotetext{
${ }^{2}$ Undang-Undang No. 23 Tahun 2002 tentang Perlindungan Anak pasal 59, dikutip dari Himpunan Peraturan Perundang-undangan Republik Indonesia, (Bandung: Nuansa Aulia, 2010).
} 
dari orang dewasa atau orang tua. Dalam istilah yang lain, bahwa masalah sosial anak merupakan efek domino dari persoalan masyarakat yang lebih luas. Sebagai sebuah gambaran kondisi kemiskinan masyarakat secara lebih luas, berkontribusi secara signifikan terhadap muncul beberapa masalah sosial anak. Buruknya penanganan masalah sosial anak merepresentasi buruknya tata kelola negara. Padahal masalah sosial anak akan berefek pada buruknya kondisi kehidupan bermasyarakat, berbangsa dan bernegara.

\section{Bentuk-bentuk Masalah Sosial Anak}

Sebelum membahas lebih jauh tentang bentuk-bentuk masalah sosial anak, maka terlebih dahulu perlu dipahami secara konseptual tentang apa yang dimaksudkan dengan masalah sosial anak. Banyak kalangan memberikan definisi tentang masalah sosial anak. Konsepsi tersebut tentu sangat dipengaruhi oleh perspektif mereka dalam melihat dan memahami masalah sosial anak. Anak bermasalah sosial biasa juga disebut dengan istilah anak rawan, tingkat kerawanan anak dapat dipahami sebagai suatu situasi, kondisi, dan tekanan-tekanan kultur maupun struktur yang menyebabkan mereka belum atau tidak terpenuhi hak-haknya dan bahkan acap kali dilanggar hakhaknya, menyebabkan mereka menjadi inferior, rentan dan termarginalkan. Inferioritas anak menjadikan mereka tersisih dari kehidupan normal dan terganggu proses tumbuh kembangnya secara wajar. Mereka yang rentan dan marginal, kehidupannya sering menjadi korban situasi sosial, tereksploitasi dan mengalami diskriminasi, serta perlakukan salah oleh lingkungannya. ${ }^{3}$

Kerawanan pada anak sehingga berakibat mengalami masalah sosial, dijelaskan dalam dokumen PBB dalam beberapa kategori sebagai berikut:

1. Anak berada dalam lingkungan di mana hubungan antara anak dan orang-orang di sekitarnya, khususnya orang dewasa, penuh dengan kekerasan atau cenderung tidak peduli atau menelantarkan.

2. Anak berada dalam lingkungan yang mengalami konflik bersenjata.

3. Anak berada dalam situasi ikatan kerja, baik formal maupun informal, yang berakibat pada perkembangan dan pertumbuhannya kurang memperoleh perhatian dan perlindungan yang memadai.

\footnotetext{
${ }^{3}$ Bagong Suyanto, Masalah Sosial Anak, (Jakarta: Kencana, 2003), hlm. 4.
} 
4. Anak yang bekerja di tempat kerja dengan resiko kerja yang tinggi.

5. Anak terlibat dalam penggunaan zat-zat psikoaktif.

6. Anak yang kondisi fisiknya cacat (baik karena bawaan atau kecelakaan), latar belakang budaya (minoritas), sosial budaya dan ekonomi orang tuanya rentan terhadap berbagai perlakuan diskriminatif.

7. Anak yang karena status perkawinan orang tuanya, rentan terhadap tindakan diskriminatif.

8. Anak yang sedang berhadapan dan mengalami masalah dengan hukum dan harus berurusan dengan dengan aparat penegak hukum beserta semua pranatanya. ${ }^{4}$

Anak-anak yang bermasalah sosial seperti anak jalanan, anak yang berkonflik dengan hukum, anak pengguna narkoba, anak korban traficking serta anak terlantar secara medis merupakan anak yang rentan atau menghadapi resiko yang besar tertular HIV/AIDS. Menurut catatan Kementerian Sosial pada tahun 30\% dari total pelaku prostitusi yang jumlahnya mencapai 70 ribu masih anak-anak. Itu baru yang tercatat, belum angka riil di lapangan yang tidak tercatat. Mereka ini yang sangat mudah terpapar HIV/AIDS. ${ }^{5}$ Indonesia saat ini menduduki posisi nomor tiga setelah Cina dan Vietnam dalam kasus HIV/AIDS terbanyak di dunia. Sementara, dilihat dari aspek pertumbuhan, di wilayah Pasifik, Indonesia menduduki posisi kedua setelah Papua Nugini.

Untuk memberikan gambaran yang komprehensif tentang beberapa persoalan sosial anak, maka pada bagian ini penulis paparkan tentang beberapa masalah sosial anak. Pilihan beberapa kasus ini, dengan pertimbangan merupakan masalah sosial anak yang memiliki mata rantai yang panjang terhadap terjadinya masalah sosial lainnya.

${ }^{4}$ Lihat Irwanto, 1999, Konvensi Vol III No.3 April 1999, dalam ibid., hlm. 4 -5.

5 "Anak Bermasalah Sosial Rentan Tertular HIV/AIDS" dalam http://www. jurnalnet.com/konten.php?nama=BeritaUtama\&topik=7\&id=925 unduh pada jam 06.00, tanggal 2 Februari 2011. 


\section{Kekerasan terhadap Anak (Child Abuse)}

Kekerasan terhadap anak adalah tindakan atau peristiwa yang berakibat pada pelukaan anak secara fisik, mental atau seksual yang umumnya dilakukan oleh orang-orang yang mempunyai tanggung jawab terhadap anak yang berakibat pada kerugian dan ancaman kesehatan dan kesejahteraan anak. ${ }^{6}$ Berangkat dari definisi tersebut maka bentuk-bentuk kekerasan terhadap anak cukup beragam.

Bentuk kekerasan yang seringkali dialami anak dari yang paling sederhana yaitu berupa kekerasan fisik dalam bentuk pemukulan yang berakibat luka pada anak hingga kekerasan mental/seksual. Tindak kekerasan fisik sederhana pada anak, kalau dilakukan berulang-ulang apalagi pelakunya orang dekat misal orang tua, bisa berakibat pada kekerasan mental. Anak-anak yang mengalami situasi ini akan merekam dalam ingatannya, untuk jangka waktu yang lama. Ekspresi dari rekaman pengalaman tersebut bisa berupa anak menjadi inferior atau rendah diri dan asosial, atau anak menjadi sangat agresif sehingga jiwa meledak-ledak dan mengekspresikan dalam bentuk tindak kekerasan terhadap orang lain.

Untuk lebih jelasnya bentuk-bentuk kekerasan terhadap anak dapat penulis paparkan sebagai berikut: ${ }^{7}$

a. Kekerasan fisik; merupakan bentuk kekerasan yang sangat mudah dikenali dan diidentifikasi. Kekerasan fisik terhadap anak bis berupa: pukulan, tamparan, tendangan, tinju, cekik, benturan, gigitan dan lainlain.

b. Kekerasan psikis/mental; merupakan bentuk kekerasan yang tidak mudah dikenali. Dampak dari tindak kekerasan ini perasaan anak yang menjadi tidak nyaman, aman, tenteram, penuh kecemasan dan menyebabkan harga diri korban turun. Bentuk nyata dari tindak kekerasan psikis diantaranya; pernyataan kasar, penyalahgunaan kepercayaan, mempermalukan seseorang di depan orang lain atau umum, pernyataan yang bersifat mengancam.

\footnotetext{
${ }^{6}$ Bagong Suyanto, op. cit., hlm. 28.

${ }^{7}$ Ibid., hlm. 29-30.
} 
c. Kekerasan seksual; merupakan segala bentuk tindakan yang bersifat mengancam atau memaksa untuk melakukan hubungan seksual (sexual intercourse), melakukan penyiksaan atau bertindak sadis dan meninggalkan korban termasuk di dalamnya anak-anak setelah melakukan hubungan seksual. Bentuk nyata dari tindak kekerasan seksual diantaranya; pelecehan seksual (pada anak bisa terjadi di sekolah, keluarga, lingkungan sekitar rumah dan berbagai tempat umum), tindak pencabulan dan perkosaan.

d. Kekerasan ekonomi; merupakan bentuk tindak kekerasan yang berhubungan dengan kebutuhan ekonomi anak dan keluarga. Bentuk nyata dari tindak kekerasan ini berupa tidak adanya pemenuhan kebutuhan ekonomi anak, pemaksaan secara langsung atau tidak langsung terhadap anak untuk bekerja mencari nafkah untuk memenuhi kebutuhan keluarga atau orang tua. Fenomena anak penjaja asongan, pengamen, ojek payung di tempat umum, mengemis dan lain-lain merupakan contoh nyata.

Bentuk-bentuk kekerasan terhadap memiliki kecenderungan yang meningkat seiring kemajuan zaman. Apalagi di kota-kota besar yang semakin banyak penduduk miskin perkotaannya. Banyak keluarga miskin yang memperlakukan anak semena-mena, menelantarkan dan bahkan memaksa mereka untuk bekerja, pada usia anak yang seharusnya kebutuhan utamanya adalah belajar dan bermain.

Secara umum bentuk-bentuk kekerasan terhadap anak mengalami peningkatan. Perkosaan (kekerasan seksual) merupakan kasus yang paling banyak ditangani Pusat Krisis Terpadu (PKT) PKT RSCM. Menyusul berikutnya kekerasan seksual non perkosaan. Kekerasan seksual pada anak laki-laki juga terjadi, setiap tahunnya cenderung meningkat. Contoh kasus kekerasan terhadap anak di Jakarta dapat dilihat dalam data kasus yang di tangani Pusat Krisis Terpadu (PKT) Rumah Sakit Cipto Mangunkusumo (RSCM) dari tahun 2000 hingga 2008 sebagai berikut: 
Tabel 1

Kasus Kekerasan terhadap Anak yang Ditangani Pusat Krisis Terpadu (PKT) Rumah Sakit Cipto Mangunkusumo Tahun 2000-2008

\begin{tabular}{|l|c|c|c|c|c|c|c|c|c|c|}
\hline \multicolumn{1}{|c|}{ KASUS } & Jun $\mathbf{0 0}$ & $\mathbf{2 0 0 1}$ & $\mathbf{2 0 0 2}$ & $\mathbf{2 0 0 3}$ & $\mathbf{2 0 0 4}$ & $\mathbf{2 0 0 5}$ & $\mathbf{2 0 0 6}$ & $\mathbf{2 0 0 7}$ & $\mathbf{2 0 0 8}$ & Total \\
\hline $\begin{array}{l}\text { Perkosaan anak } \\
\text { perempuan }< \\
18 \text { th) }\end{array}$ & 74 & 103 & 127 & 127 & 148 & 120 & 117 & 123 & 168 & $\mathbf{1 1 0 7}$ \\
\hline $\begin{array}{l}\text { Kekerasan } \\
\text { seksual lain } \\
\text { anak } \\
\text { perempuan } \\
\text { (<18 th) }\end{array}$ & 23 & 92 & 136 & 132 & 129 & 105 & 111 & 91 & 97 & $\mathbf{9 1 6}$ \\
\hline $\begin{array}{l}\text { Kekerasan } \\
\text { seksual anak } \\
\text { laki-laki (<18 th) }\end{array}$ & 5 & 5 & 7 & 18 & 22 & 23 & 23 & 20 & 35 & $\mathbf{1 5 8}$ \\
\hline $\begin{array}{l}\text { Penderaan } \\
\text { anak }\end{array}$ & 7 & 10 & 6 & 7 & 14 & 9 & 14 & 15 & 34 & $\mathbf{1 1 6}$ \\
\hline $\begin{array}{c}\text { Penelantaran } \\
\text { anak }\end{array}$ & 2 & 0 & 0 & 1 & 0 & 0 & 0 & 0 & 0 & $\mathbf{3}$ \\
\hline Jumlah & $\mathbf{1 1 1}$ & $\mathbf{2 1 0}$ & $\mathbf{2 7 6}$ & $\mathbf{2 9 5}$ & $\mathbf{3 1 3}$ & $\mathbf{2 5 7}$ & $\mathbf{2 6 5}$ & $\mathbf{2 4 9}$ & $\mathbf{3 3 4}$ & $\mathbf{2 3 0 0}$ \\
\hline
\end{tabular}

Data dari diperoleh dari materi panel Dr.Suryo (salah satu pengelola PKT RSCM) dalam Konferensi Nasional I Pengetahuan dari Perempuan Indonesia Jakarta 28 November s/d 1 Desember 2010

\section{Anak Jalanan}

Anak jalanan merupakan bagian buram dari potret dunia anak di Indonesia jumlahnya terus meningkat seiring kemajuan pembangunan. Selama ini anak jalanan merupakan bagian dari fenomena sosial di perkotaan besar. Di Jakarta pada pertengahan tahun 90-an jumlah anak jalanan mencapai kisaran angka 10 ribu hingga 20 ribu anak. ${ }^{8}$ Persebaran mereka dapat dilihat diberbagai pusat keramaian Jakarta seperti pasar, terminal, mal, pusat-pusat pertokoan, stasiun, perempatan jalanan dan lain-lain.

Secara konseptual ada beberapa pandangan yang berbeda tentang anak jalanan. Adapun batasan definitif untuk menentukan apakah seorang anak itu masuk kategori sebagai anak jalanan penulis menggunakan pendapat Silva (1996) yang memberikan tiga pengertian tentang anak jalanan sebagai berikut:

8 Sumardi (1996), lihat dalam Wahyu Nurharjadmo, Seksualitas Anak Jalanan, Seri Laporan No. 85, laporan penelitian Kerjasama Ford Foundation dengan Pusat Penelitian Kependudukan Universitas Gadjah Mada, Yogyakarta, 1999, hlm. 1 
a. Anak-anak yang benar-benar hidup dan bekerja di jalanan dan ditelantarkan atau telah lari dari keluarga mereka.

b. Anak-anak yang menjaga hubungan dengan keluarga mereka, tetapi menghabiskan waktunya di jalanan.

c. Anak-anak dari keluarga yang hidup di jalanan. ${ }^{9}$

Munculnya disebabkan oleh banya faktor diantaranya adalah beban ekonomi pada keluarga miskin kota yang berat, sehingga orang tua tidak mampu memberikan perhatian dan memenuhi kebutuhan dasar mereka, berupa makan, pakaian, perumahan, pendidikan, kesehatan dan kasih sayang secara layak. Lebih-lebih perlindungan dari kerasnya kota. Realitas ini yang mengantarkan anak-anak mereka turun di jalanan untuk mensupport pemenuhan kebutuhan dasar keluarga. Mereka harus memenuhi kebutuhan sendiri dengan menjajakan Koran, makanan dan minuman sebagai pedagang asongan, pengemis dan pengamen di perempatan jalan dan di atas angkutan umum serta terminal. Bahkan ada sebagian yang harus terjun di dunia hitam sebagai pengedar narkoba, pencopet dan pengompas.

Untuk memahami pengertian dan dinamika anak jalanan perlu peneliti jelaskan tentang klasifikasi anak jalanan berdasarkan akar permasalahan yang menyebabkan mereka menjadi anak jalanan sebagai berikut:

a. Karena orang tua yang kurang perhatian kepada anak-anaknya sehingga anak mencari perhatian di jalanan. Hal ini dapat dilihat tindakan-tindakan mereka yang kebut-kebutan, vandalisme, tawuran dan lain-lainnya.

b. Karena problema kemiskinan orang tua sehingga tidak mampu untuk bersekolah akhirnya mereka menjadi anak jalanan. ${ }^{10}$

Mendasarkan kepada klasifikasi tersebut di atas maka bisa diambil dua definisi tentang anak jalanan sebagai berikut: pertama, secara sosiologis menunjuk kepada aktivitas sekelompok anak yang keluyuran di jalan-jalan, hlm. 2 .

${ }^{9}$ Lihat dalam Wahyu Nurharjadmo, Seksualitas Anak Jalanan, Seri Laporan No. 85, hlm. 78 .

${ }^{10}$ Heru Nugroho, Menumbuhkan Ide-ide Kritis, (Yogyakarta: Pustaka Pelajar, 2000). 
orang awam mengatakan sebagai kenakalan anak dan mereka dianggap mengganggu ketertiban sosial. Kedua, pengertian ekonomi menunjuk kepada aktibitas sekelompok anak (pekerja anak) yang terpaksa mencari nafkah di jalanan karena kondisi ekonomi orang tua yang miskin. ${ }^{11}$

Kehidupan yang bebas lepas dari kendali keluarga atau bahkan telah putus hubungan dengan keluarga dan berkeliaran di tempat-tempat umum merupakan situasi yang rentan bagi anak jalanan untuk berperilaku menyimpang. Berbagai ancaman sosial selalu menghantui mereka. Sewaktu-waktu mereka bisa saja terkena operasi penertiban oleh petugas pengamanan, dan penertiban kota, sehingga akan mendapatkan perlakuan yang semena-mena. Begitu pula perlakuan semena-mena atau tindak kekerasan dari sesama anak jalanan, karena pola kehidupan bebas seperti itu hukum rimba yang berlaku. Masalah sosial yang lain yang dapat menjerumuskan kehidupan anak jalanan ke lembah hitam kehidupan kota diantaranya; perilaku minum-minuman keras, penggunaan obat-obatan terlarang, terserang penyakit menular seksual akibat dari perilaku hubungan seksual bebas, prostitusi dan perdagangan orang. Byrne (1992) melakukan penelitian di Rio de Janeiro Brasil menemukan data bahwa anak jalanan laki-laki sudah mengenal dan menggunakan obat-obatan dan minum-minuman keras sejak usia 8 tahun. Mereka sudah aktif berhubungan seksual sejak berusia 12 tahun. $^{12}$

\section{Anak Berhadapan dengan Hukum $(\mathrm{ABH})$}

Jumlah anak yang harus berhadapan dengan hukum cukup banyak, menurut data sementara Markas Besar Kepolisian RI, selama tahun 2008 ada 811 anak yang harus berhadapan dengan hukum karena beberapa masalah. Diantaranya penganiayaan, pencurian, pemerasan, pencabulan, perkosaan, dan pelecehan seksual. Sementara menurut data Direktorat Jenderal Pemasyarakatan, jumlah anak yang harus menjalani hukuman di

\footnotetext{
11 Ibid., hlm. 78.

12 Lihat dalam Wahyu Nurharjadmo, Seksualitas Anak Jalanan, Seri Laporan No. 85,
} hlm. 2. 
rumah tahanan/lembaga pemasyarakatan untuk anak meningkat dari tahun ke tahun. Tahun 2004, penghuni rumah tahanan/lembaga pemasyarakatan anak sebanyak 3.653 anak dan meningkat menjadi 4.301 anak pada 2007. ${ }^{13}$

Penyimpangan tingkah laku atau perbuatan melanggar hukum yang dilakukan oleh anak, dikarenakan adanya perubahan sosial dalam masyarakat akibat dari adanya perkembangan ilmu pengetahuan dan teknologi, perkembangan sistem komunikasi dan informasi, perubahan gaya dan cara hidup orang tua. Dampaknya sangat terasa pada nilai dan perilaku anak. Perilaku anak yang melanggar hukum dipengaruhi oleh pola asuh dalam keluarganya. Anak-anak yang kurang mendapatkan kasih sayang, asuhan, bimbingan dan pembinaan dalam pengembangan sikap, perilaku, penyesuaian diri, dan pengawasan orang tua, wali, dan orang tua asuh merupakan anak-anak yang sangat rentan berperilaku melanggar hukum. ${ }^{14}$

Perilaku menyimpang anak sebagai bentuk kenakalan remaja atau kejahatan akan mengalami peningkatan kualitas dan tingkat tindak kekerasan (kebengisan/kesadisan) yang tinggi manakala dilakukan secara kolektif dan terorganisir daripada yang dilakukan secara individual. ${ }^{15}$ Anak remaja akan meningkat keberaniannya dalam berperilaku menyimpang jika diprovokasi/didukung oleh teman sebayanya. Sentimen kelompok bisa menjadi pemicu atau alat sugesti untuk mendorong mereka melanggar hukum atau norma- norma masyarakat. Kehidupan kelompok anak remaja yang terorganisir melakukan kejahatan atau gang akan memproduksi terusmenerus perilaku tersebut. Bahkan keberanian dalam melakukan kejahatan menjadi tolak ukur loyalitas mereka pada kelompok. Penentuan ketua geng pun seringkali parameternya adalah keberanian dan frekuensi dalam melakukan kejahatan, sehingga ketua kelompok merupakan anak yang paling pemberani.

\footnotetext{
${ }^{13}$ Lihat dalam http://bataviase.co.id/detailberita-10502246.html diunduh pada jam 10.30, tanggal 2 Februari 2011.

14 Lihat dalam Penjelasan atas Undang-Undang No. 3 Tahun 1997 tentang Pengadilan Anak.

${ }^{15}$ Minddendorff (1960), lihat dalam Kartini Kartono, Patologi Sosial II: Kenakalan Remaja, (Jakarta: Rajagrafindo, 2006).
} 
Fakta di lapangan menunjukkan bahwa kemajuan ekonomi suatu kawasan atau negara berkorelasi positif terhadap peningkatan tindak kejahatan anak remaja baik secara kuantitas maupun kualitas. Kemajuan ekonomi karena industrialisasi menjadikan sifat individualisme masyarakat meningkat. Kontrol sosial masyarakat menjadi longgar, sehingga anak remaja yang berproses membentuk jati dirinya berkembang dan tumbuh secara bebas. Kebebasan inilah yang menyebabkan mereka tumbuh secara tidak wajar dan berani melakukan tindakan-tindakan yang melanggar hukum atau norma.

Beberapa bentuk kejahatan yang dilakukan anak remaja di kota-kota diantaranya mencopet, menjambret, menipu, tawuran, pengedar narkoba dan lain-lain. Pelaku tindak kejahatan pada anak remaja umumnya didominasi anak laki-laki, daripada anak perempuan. Kecenderungan dari bentuk perilaku menyimpang anak perempuan adalah sebagai penjaja seksual komersial. ${ }^{16}$ Motif utama perilaku tersebut bermacam-macam, diantaranya faktor psikologis dan ekonomi. Namun faktor ekonomi lebih dominan. Gaya hidup anak remaja yang pragmatis dan hedonis menjebak mereka untuk melakukan kejahatan dalam rangka mendapatkan uang secara mudah, cepat, dan banyak. Sementara mereka mayoritas belum memiliki pekerjaan tetap.

Trend tawuran di kalangan pelajar di Indonesia dalam kondisi yang memprihatinkan. Dahulu orang mendengar tawuran pelajar, pasti akan menunjuk kota Jakarta. Sekarang fenomena tersebut telah meluas di berbagai kota, sampai kota-kota kecil. Sebuah contoh kasus:

sejumlah pelajar yang mengikuti upacara HUT RI Kota Ternate yang berlangsung di stadion Gelora Kieraha, Ternate, terlibat tawuran usai mengikuti upacara. Para pelajar yang merupakan siswa SMKN 2 dan SMUN 1 Ternate ini terlibat perkelahian massal saat keluar dari dalam stadion. Lokasi meletusnya tawuran tersebut tepatnya sekira 100 meter dari stadion atau di depan gedung DPRD Maluku Utara (Malut). Kontan, kejadian tersebut sempat membuat

${ }^{16}$ Ibid., hlm. 7. 
heboh suasana HUT RI di kota itu. Aparat kepolisian yang berjagajaga di sekitar lokasi perayaan hari kemerdekaan sigap meredam aksi tawuran yang berlangsung beberapa menit itu. Sehingga kericuhan bisa segera dihentikan. Para pelajar itu kemudian digiring secara terpisah agar tidak memunculkan perkelahian baru. Salah seorang petugas di lokasi kejadian yang dikonfirmasi menyatakan tidak tahu persis penyebab tawuran tersebut. ${ }^{17}$

Dampak hukum dari pelaku tawuran akan muncul ketika anak melakukan tindakan anarkhis merusak fasilitas umum dan bahkan membunuh pihak lawannya. Ketika itu terjadi maka pelakunya akan dikenakan tindak pidana anak. Dalam situasi ini maka anak dikategorisasikan sedang berhadapan dengan hukum.

\section{Penanganan Anak-anak Bermasalah Sosial}

Penanganan kasus anak bermasalah sosial, harus mendasarkan kasus perkasus karena masing-masing memiliki keragaman masalah yang berbeda-beda. Pendekatan penyelesaian masalah secara kasus perkasus akan menunjukkan keberpihakan pada anak yang bermasalah. Ketika penanganan tidak berpihak pada mereka, maka akan sangat sulit untuk menolong mereka. Apalagi kalau pendekatannya bersifat general dan seragam akan sangat jauh dari akar masalah. Meskipun masalah sosial anak bisa jadi saling berkaitan satu dengan yang lainnya. Sebagai gambaran menangani kasus anak korban kekerasan, anak jalanan dan anak berhadapan dengan hukum masing-masing memiliki cara yang berbeda.

Peningkatan keberfungsian keluarga dalam masyarakat harus dilakukan karena keluarga merupakan utama dari merebaknya masalah sosial anak. Anak-anak yang terlahir dalam keluarga yang buruk hubungan antar anggota keluarganya terutama kedua orang tua, memiliki potensi tinggi terhadap munculnya masalah sosial anak yang lebih luas di masyarakat. Apalagi amanat Undang-Undang Republik Indonesia Nomor 23 Tahun

\footnotetext{
${ }^{17} \mathrm{http}: / /$ news.okezone.com/index.php/ReadStory/2008/08/17/1/137530 diunduh jam 21.56. tanggal 19/2/2011
} 
2002 tentang Perlindungan Anak pasal 26 sangat jelas menyebutkan bahwa orang tua berkewajiban dan bertanggung jawab untuk:

1. Mengasuh, memelihara, medidik dan melindungi anak;

2. Menumbuhkembangkan anak sesuai dengan kemampuan, bakat dan minatnya;

3. Mencegah terjadinya perkawinan pada usia anak-anak.

Penanganan anak korban tindak kekerasan harus secara komprehensif dengan mempertimbangkan aspek fisiologis, psikis dan sosiologis. Apalagi anak-anak korban kekerasan seksual perkosaan. Beban psikisnya tentu sangat berat, begitu pula beban sosiologisnya. Mereka cenderung sangat traumatis, secara sosial dia akan terasingkan oleh lingkungannya. Proses rehabilitasi medis dan psikis harus dilakukan secara simultan. Untuk mengurangi beban traumatis, maka perlu pendampingan oleh konselor dan psikolog yang sensitif pada korban. Untuk penanganan hukum maka proses hukum harus disertai pendamping sehingga korban kuat dan berani mengungkap kasus yang dialaminya.Terhadap pelaku tindak kekerasan terhadap anak yang berkategori berat dan pelaku orang dewasa harus dihukum berat agar tindakan tersebut diulang atau terulang oleh pelaku lain.

Penanganan anak jalanan di Indonesia selama ini, dilakukan oleh negara dan masyarakat sebagai komunitas atau pun lembaga swadaya masyarakat (LSM). Keterbatasan kemampuan negara menangani persoalan anak jalanan mendorong masyarakat atau lembaga swadaya masyarakat (LSM) dengan cara mencari donor (fundrising) dari pihak swasta atau donor asing. Hadirnya LSM dalam penanganan masalah sosial anak seringkali menjadi lembaga alternatif yang lebih mudah diterima oleh anak jalanan. Mereka mengembangkan kreativitas dalam rangka pemberdayaan dan berperspektif kebutuhan anak jalanan. Sedangkan pemerintah kecenderungannya mengedepankan upaya preventif dengan menggaruk anak-anak jalanan dari komunitasnya di jalan, karena dianggap sebagai komunitas yang mengganggu kenyamanan kehidupan kota.

Upaya mengatasi persoalan anak jalanan harus berbasis pada realitas di lapangan. Oleh karena itu pemetaan terhadap posisi mereka, pola hubungan 
diantara dan upaya yang selama ini mereka lakukan dalam rangka membangun komunitas mereka penting untuk diketahui. Begitu pula bentukbentuk aktivitas rutin yang selama ini menjadikan mereka eksis juga perlu dipahami secara lebih mendalam. Kemudian hubungan aktivitas rutin tersebut terhadap masyarakat di lingkungannya. Hal yang penting juga bagaimana setting keluarga atau sosial yang selama ini melatar belakangi kehidupan mereka. Bagaimana harapan-harapan mereka tentang aktivitas yang selama ini mereka jalani. Persoalan yang mereka hadapi dalam eksistensi mereka penting. Kemudian lamanya mereka beraktivitas di jalanan.

Berbagai pendekatan bisa dilakukan untuk mengatasi merebaknya anak jalanan di masyarakat. Pilihan pendekatan tersebut tentunya sangat dipengaruhi oleh cara pandang masyarakat atau negara terhadap keberadaannya. Beberapa alternatif sebagai solusi terhadap persoalan anak jalanan, bisa berangkat dari proses yang bersifat peningkatan kualitas hidup mereka hingga yang paling ekstrem penghapusan posisi mereka.Untuk lebih jelasnya dapat dilihat beberapa solusi sebagai berikut:

1. Pendekatan penghapusan (abolition) dengan upaya menghapus gejala anak jalanan secara radikal dan menyeluruh.

2. Pendekatan perlindungan (protection), yang berupaya melindungi hakhak anak jalanan seperti juga hak-hak anak lainnya dengan tidak berpretensi menghapus anak jalanan.

3. Pendekatan pemberdayaan (empowerment), yang berupaya mereduksi jumlah anak-anak jalanan dengan cara memberdayakan mereka supaya berpikiran kritis, baik secara ekonomi, sosial, budaya dan politik. Ketiga pendekatan ini diterapkan sesuai dengan motif politik dan konteks sosial budaya masyarakat yang bersangkutan. ${ }^{18}$

Penanganan anak yang sedang berhadapan dengan hukum harus berorientasi pada tumbuh kembang anak. Tindakan salah dalam menangani anak bermasalah dengan hukum, justru akan menjerumuskannya lebih dalam. Penanganan anak bermasalah dengan hukum harus dilakukan dalam rangka pembinaan, pendidikan, dan pengembangan perilaku mereka

${ }^{18}$ Heru Nugroho, Menumbuhkan Ide-ide Kritis, ....... hlm. 82. 
menuju perilaku yang sesuai dengan aturan atau norma-norma dalam masyarakat. Penanganan kasus anak yang bermasalah dengan hukum jangan diorientasikan pada upaya penghukuman agar jera, cara tersebut akan mempengaruhi psikologisnya. Mereka akan merasa terstigma sebagai seorang mantan hukuman atau narapidana.

\section{E. Penutup}

Masalah sosial anak dari waktu ke waktu terus meningkat seiring kemajuan zaman, maka berbagai upaya, harus dilakukan oleh keluarga, masyarakat dan negara. Tiga pilar tersebut harus saling bekerjasama untuk satu tujuan menyelamatkan kehidupan anak dan masa depan bangsa dan negara. Masyarakat dan negara akan baik jika dibangun atas dasar penyiapan generasi muda khusunya anak-anak secara baik pula. Problem sosial anak yang terus meningkat harus diselesaikan secara komprehensip dan lintas sektoral. Di Indonesia secara kelembagaan sesungguhnya negara telah mengakomodasi kebutuhan penyelesaian problem anak, dalam bentuk regulasi, kelembagaan, program dan anggaran. Multi pendekatan dalam menangani problem sosial anak dilakukan agar solusi bersifat jangka panjang dan purna. Ketika solusi bersifat jangka pendek dan pendekatan proyek maka anak sangat pontensial kembali mengalami masalah sosial. Secara teknis penanganan anak hraus mengakomodasi hak-hak anak sebagai hak asasinya. Anka yang telah mengalami atau menghadapi masalah sosial, harus menggunakan pendekatan yang berorientasi pada kebutuhan dan dunia anak. Jangan sampai upaya penanganan terhadap masalah sosial anak justru menyebabkan anak terjerumus ke dalam masalahnya lebih dalam, ketika semua ini terjadi maka sangat sulit untuk merehabilitasi anak kembali ke dalam masyarakatnya secara wajar.]

\section{Daftar Pustaka}

Dwi, Narwoko, J., \& Bagong Suyanto, (editor), Sosiologi Teks Pengantar dan Terapan, Jakarta: Kencana, 2010. 
Evers, Hans Dieter, Sosiologi Perkotaan, Jakarta: LP3ES, 1986.

Horton, Paul B., dan Hunt, Chester L., Sosiologi, jilid I dan II, Jakarta: Erlangga, 1992.

Kartono, Kartini, Patologi Sosial II: Kenakalan Remaja, Jakarta: Rajagrafindo, 2006.

Leur, Robert H., Perspektif-perspektif tentang Perubahan Sosial, Jakarta: Bina Aksara, 1986.

Nurharjadmo, Wahyu, Seksualitas Anak Jalanan, Seri Laporan No. 85, Laporan Penelitian Kerjasama Ford Foundation dengan Pusat Penelitian Kependudukan Universitas Gadjah Mada, Yogyakarta, 1999.

Nugroho, Heru, Menumbuhkan Ide-ide Kritis, Yogyakarta: Pustaka Pelajar, 2000.

Suyanto, Bagong, Masalah Sosial Anak, Jakarta: Kencana, 2003.

Penjelasan atas Undang-undang Republik Indonesia Nomor 3 Tahun 1997 tentang Pengadilan Anak.

Undang-undang Republik Indonesia No. 23 Tahun 2002 tentang Perlindungan Anak dari Himpunan Peraturan Perundang-undangan Republik Indonesia, Bandung: Nuansa Aulia, 2010.

http://news.okezone.com/index.php/ReadStory/2008/08/17/1/137530 diunduh jam 21.56. tanggal 19/2/2011

http://bataviase.co.id/detailberita-10502246.html diunduh pada jam 10.30, tanggal 2 Februari 2011.

http://edukasi.kompas.com/read/2010/02/17/12463026/Jumlah.Anak.Bermas alah.Indonesia.Setara.Jumlah.Penduduk.Singapura. Unduh jam 7.33 pada tanggal 2 Februari 2011.

http://www.jurnalnet.com/konten.php?nama=BeritaUtama\&topik=7\&id=925 unduh pada Jam 06.00, tanggal 2 Februari 2011. 